\title{
Images of the Croatian Borderlands: Selected Examples of Early Modern Cartography
}

\author{
Borna Fürst - Bjeliš, Ivan Zupanc
}

\begin{abstract}
Although maps have long been central to geographical inquiry, they were rarely treated as text or socially constructed images in general as well as in Croatian historical geography and history of cartography.

Looking at maps as images, i.e. social constructions of reality in Harleyan, postmodern terms, the paper discusses the images of the Croatian borderlands in the early modern period. This is the period of frequent changes of borders between three imperial systems with different religious systems and cultural traditions that have met on the Croatian territory, and consequently reflected different attitudes toward the borderlands. The analysis is made on the basis of original maps from Croatian cartographic funds, as well as on a number of published facsimiles, mainly from the $17^{\text {th }}$ and $18^{\text {th }}$ century.

It is possible to define two levels of meanings of the analyzed maps. The first one is related to the specific relation of the state authorities to border region, their particular interests and understanding of its importance. The other one reveals common socio-cultural images of the borderlands. Constructed in the distinct and complex border circumstances of the $16^{\text {th }}-18^{\text {th }}$ century, they disappear from the maps with the change of circumstances that created them.
\end{abstract}

Key words: cartographic sources, history of cartography, socio-cultural aspect of cartography, historical geography, historical borders of Croatia, $16^{\text {th }}-18^{\text {th }}$ century

\section{Percepcije hrvatskog graničja: odabrani primjeri novovjekovne kartografije}

Iako su karte oduvijek u središtu geografskog zanimanja, rijetko se o njima razmišljalo kao o tekstu ili pak društveno uvjetovanim slikama, odnosno percepcijama, kako općenito tako i u hrvatskoj historijskoj geografiji i povijesti kartografije.

Shvaćajući karte kao percepcije, odnosno socijalne konstrukcije stvarnosti u Harleyanskim, postmodernim okvirima, u radu se raspravlja o percepcijama hrvatskog graničja u ranom novom vijeku. To je razdoblje čestih promjena granica između tri imperijalna sustava s različitim religijskim sustavima, kao i različitim kulturnim tradicijama koje su se susrele na hrvatskom prostoru. Analiza je provedena na temelju izvornih karata dostupnih u kartografskim fondovima hrvatskih institucija, kao i na temelju brojnih publiciranih faksimila, uglavnom iz 17. i 18. stoljeća.

Moguće je definirati dvije razine značenja analiziranih karata. Prva je vezana uz posebne odnose državnih vlasti prema graničnom području, njihovim specifičnim interesima 
i razumijevanju važnosti granice. Druga razina otkriva opće sociokulturne percepcije graničja. Stvorene u posebnim i složenim uvjetima razvoja graničnog područja između 16. i 18. stoljeća, one nestaju s karata s promjenom uvjeta koji su ih stvorili.

Ključne riječi: kartografski izvori, povijest kartografije, sociokulturni vid kartografije, historijska geografija, povijesne granice Hrvatske, 16. do 18. stoljeće

\section{MAPS AS IMAGES: TEXT AND CONTEXTS OF THE MAP}

One of the essential questions posed by J. B. Harley (1990) is whether the map is a mirror, reflecting some aspect of the real world as a graphic representation or a social construction of the world expressed through the medium of cartography.

The traditional view is that the role of the map is to present a factual statement about geographical reality within the frames of actual survey techniques and the skills of the cartographer. Since the Enlightenment, cartography has been defined as factual science based on map accuracy, i. e. its degree of correspondence with topographical truth. The standard scientific model is rooted in the statement that a mirror of nature could be projected through measurements. Accordingly, the most usual approach until recently dealt with map accuracy, with describing the bibliographical and technical complexity of maps, with maps as quarry of facts (index to the location of things, processes and events) in the reconstruction of the past.

Recent researches tend to subvert the traditional, positivist model in analyzing maps, replacing it with one that is grounded in an iconological and semiotic theory of the nature of maps. Since the nineties, J. B. Harley has been arguing that maps are not just simple representations of geographic reality, and offers an alternative answer to the aforesaid question: "... an equally appropriate definition of a map is "a social construction of the world expressed through the medium of cartography". Far from holding up a simple mirror of nature that is true or false, maps redescribe the world - like any other document - in terms of relations of power and of cultural practices, preferences, and priorities. What we read on a map is as much related to an invisible social world and to ideology as it is to phenomena seen and measured in the landscape." (Harley 2001, 35-36).

Maps, in these postmodern views, should be considered as graphic language and discussed as text to be decoded rather than a mirror of nature. This is an approach derived directly from semiotics. Thus, maps are a construction of reality, images that should be put and studied in the appropriate context - the societies of their time. Maps are like books; they represent the images of both - the individual mind of the author (cartographer) and the wider cultural values in a particular society and time. However, although maps have long been central to geographical inquiry, they were rarely treated as text or socially constructed images in general as well as in Croatian historical geography and history of cartography. More often they were discussed in term of accuracy, objectiveness, authenticity etc.

As images of the world, maps are never neutral or value-free or ever completely scientific (Harley 1990). Most maps "speak" to a targeted audience, especially those produced by 
governments. The division between the "decorative" and the "scientific" phases of mapping in these terms can be recognized as a myth. More precise measurements in the "scientific" phase of cartography intensified the symbolic power of maps. Map accuracy became a new power of authorities (Harley 1988). "... universal characteristics of cartography are not only to express social and political conflicts but also to take side in them: thus every map is ideological, deploying thoughts as weapons..." (Andrews 2001, 26).

As all maps are social, political and cultural it is most important to see them in the appropriate context. That means that the particular map has to be returned to the past and situated in its proper period and place. Scholars, on the contrary, often studied maps outside the time, place or even culture. When discussing map as a text, Harley (1990) points out three aspects of the context: 1 . The context of the cartographer, 2. The contexts of other maps, 3 . The context of society. Maps are not outside society: they are part of it as constitutive elements within the wider world (Harley 2001, 44).

\section{CROATIAN BORDERLANDS AND CARTOGRAPHY IN THE EARLY MO- DERN PERIOD: THE CONTEXTS}

In the history of mapping the Croatian territory the early modern period was a turning point. The development of cartography and the progress of cartographic knowledge of Croatian lands, notably its borderlands, are directly connected with military operations; the Ottoman retreat and the peace treaty of Srijemski Karlovci in 1699. This is the period when cartography developed into so-called "military cartography" practiced in military institutions. Military engineers were the creators of new maps. However, the cartographers were rarely independent decision makers, free of financial, military or political constraints. The contexts of the cartographers also included personal skills, and the cartographer as a person living in a particular society and in particular political circumstances. Accordingly, a map could and often did represent an image with multiple layers of meanings and perceptions. Although many of those maps are little more than drawings because of the secrecy of the surrounding war operations (Pandžić 1988,16), this period is also the beginning of the creation of the first topographic sketches and genuine topographic maps of the Croatian borderlands. Topographical maps were usually made to fulfill several needs of the state or the empire. They were designed as administrative or jurisdictional records, for defense or economical development. Still, topographical maps were mostly of military origin and as such they emphasized features of strategic importance.

The peace treaty was signed between three sides; the Ottoman Empire, the Habsburg Monarchy and the Venetian Republic. On this occasion, a delimitation commission was appointed in order to establish the new boundaries, and the first detailed maps of the region were made. The commission consisted of representatives of all interested sides ${ }^{1}$. The contexts of other maps and society (or societal environment) are directly connected; they can be seen through the maps made by different actors that are reflecting individual approaches to the territory due to the specific socio-political circumstances and state power interests, as well as some spontaneous images of the Croatian borderlands, that were imbedded in the society and culture of the particular period and place. 
What one can put into relation here is Habsburg and Venetian cartography in the first place. There are no cartographic representations whatsoever from the Ottoman side that are appropriate for comparative approach. The most valuable aspect of Ottoman geography in the early modern period was in the field of the historical geography of Rumelia ${ }^{2}$, both human and physical, and not in cartography. One of the most significant compilations written during the $18^{\text {th }}$ century was "Atlas" by Bartinli Ibrahim Hamdi. Atlas, in the Ottoman terminology of the time, was a general work of geography and not a collection of maps (Orhonlu 1977). The cartographic presentation of the Ottoman side of the new border remained in the hands of the Austrian cartographers. As a representative of the Croatian Parliament with the aim of representing Croatian interests, Pavao Ritter Vitezović also joined the commission. He made several topographical maps and sketches of the border area himself, and the territory of Croatia in relation to its borders. Thus, on the third count, opposed to the Habsburg and Venetian approach, there is also a personal image of the Croatian borderlands by the Croatian cartographer P. Ritter Vitezović.

\section{CARTOGRAPHIC SOURCES}

The early modern period, notably the $18^{\text {th }}$ century, was a very fruitful period concerning map making. There exist a huge number of dominantly military maps, topographic sketches, drafts and drawings made by Habsburg officers. However most of these cartographic sources are kept outside Croatia in Austrian institutions, in War Archives and in the National Library in Vienna. The greater part of the Venetian maps of demarcation is kept in the cartographic collection of the State archives in Venice. A large number of those maps is available as facsimiles in monumental cartographic monographs of Croatia (Kozličić 1995, Marković 1993, 1998, Pandžić 1988). The present analysis is based on cartographic originals from the map collections of the Croatian State Archives, the National University Library, the Museum of Croatian History and, in addition, on the published facsimiles. A choice of maps, predominantly from $17^{\text {th }}$ and $18^{\text {th }}$ century, enable an insight into the different approaches to cartographic representations and images of the borderlands even within the framework of a single, overarching tradition.

\section{LEVELS OF MEANING}

The meaning of the map, understood in Harleyan terms as "social construction", is more concerned with significance rather than purpose. The symbolic meaning of the map, according to Harley (2001), refers to power relationships, types of social groups and their characteristics, states of mind and system of beliefs. By analyzing the available cartographic sources representing the Croatian borderlands in the early modern period, it is possible to define two levels of meaning. The first one is related to the specific relation of the state authorities to the border region, their particular interests and understanding of its importance. The other one reveals common socio-cultural images of the borderlands.

Images and perceptions that are imprinted on the maps are of different age and state of their development. Some of them could be traced back to the $16^{\text {th }}$ century, while others 
are rather new. Anyway, the fact is that they all vanished by the end of $18^{\text {th }}$ century or with a certain delay, by the beginning of $19^{\text {th }}$ century. Born in the distinct and complex border circumstances of the $16^{\text {th }}$ to $18^{\text {th }}$ century, they disappear from the maps with the change of circumstances that created them.

\section{DISSEMINATING THE POLITICAL MESSAGE OF POWER AND CONTROL}

Throughout history, as much as other weapons, maps have been an intellectual weapon of imperialism and of territorial pretensions of empires and states. In this imperial context, maps regularly supported the direct execution of territorial power. The rulers were everywhere aware of the value of maps in exercising power and control, in promotion, in giving legitimacy to the territorial occupation as well as in defense and warfare. The specific functions of maps in the exercise of power range from global empire building to the preservation of the nation state and to the assertion of local property rights.

The Venetian maps are very good examples of these. Venetian cartographic policy was primarily subordinated to the republic's political and administrative purposes. They have, generally, more information about political or administrative divisions and contain much less of geographical inventory. This is an example of direct dissemination of the political message of power and control over the territory. Many of the conventional tools in map making were used in doing this; such as deliberate or "unconscious" distortions and omissions on the maps.

The examples of Coronelli's map of Dalmatia of 1700 and Alberghetti's map of Dalmatia of 1732 enable us to distinguish two different stages for approaching the Venetian borderlands. The technique of map-making differ; Coronelli's map was still based mainly on the compilations, while Alberghetti's map is already based on field surveys. However, apart from technical differences, these maps express the political message in the corresponding way. Vincenzo Maria Coronelli, as the official Venetian cartographer, was the most prominent figure in promoting Venetian politics regarding the territorial pretensions on his maps. His maps were an important instrument for emphasizing the Venetian conquest over the Ottomans. Coronelli's map of Dalmatia is a general regional map on a rather small scale. The map charts Venetian Dalmatia, the territory of the Republic of Dubrovnik, parts of Croatia, Bosnia, Serbia and surrounding lands (Fig. 1). The whole inland area between the river Sava and the Adriatic is compressed along its north-south axis. But, on the other hand, the territory of Venetian Dalmatia is unproportionally vast, especially concerning its inland part. The northern Dalmatian border depicted on this map does not correspond to the frontier between the Venetian and Ottoman territories. It goes too far to the north, even incorporating the whole territory of the Herzegovina region into the Venetian Dalmatia. In spite of a number of possible errors, these distortions on the map are more a testimony to the expression of state power interests and an approach to the border area; emphasizing and even over-exaggerating its possessions and importance while ignoring the Ottoman side at the same time.

A new stage in presenting Venice's border regions is marked by Alberghetti's maps. As a member of the demarcation commission, he led the team of military cartographers in order to map the newly established borders after the peace treaties. The beginning of 


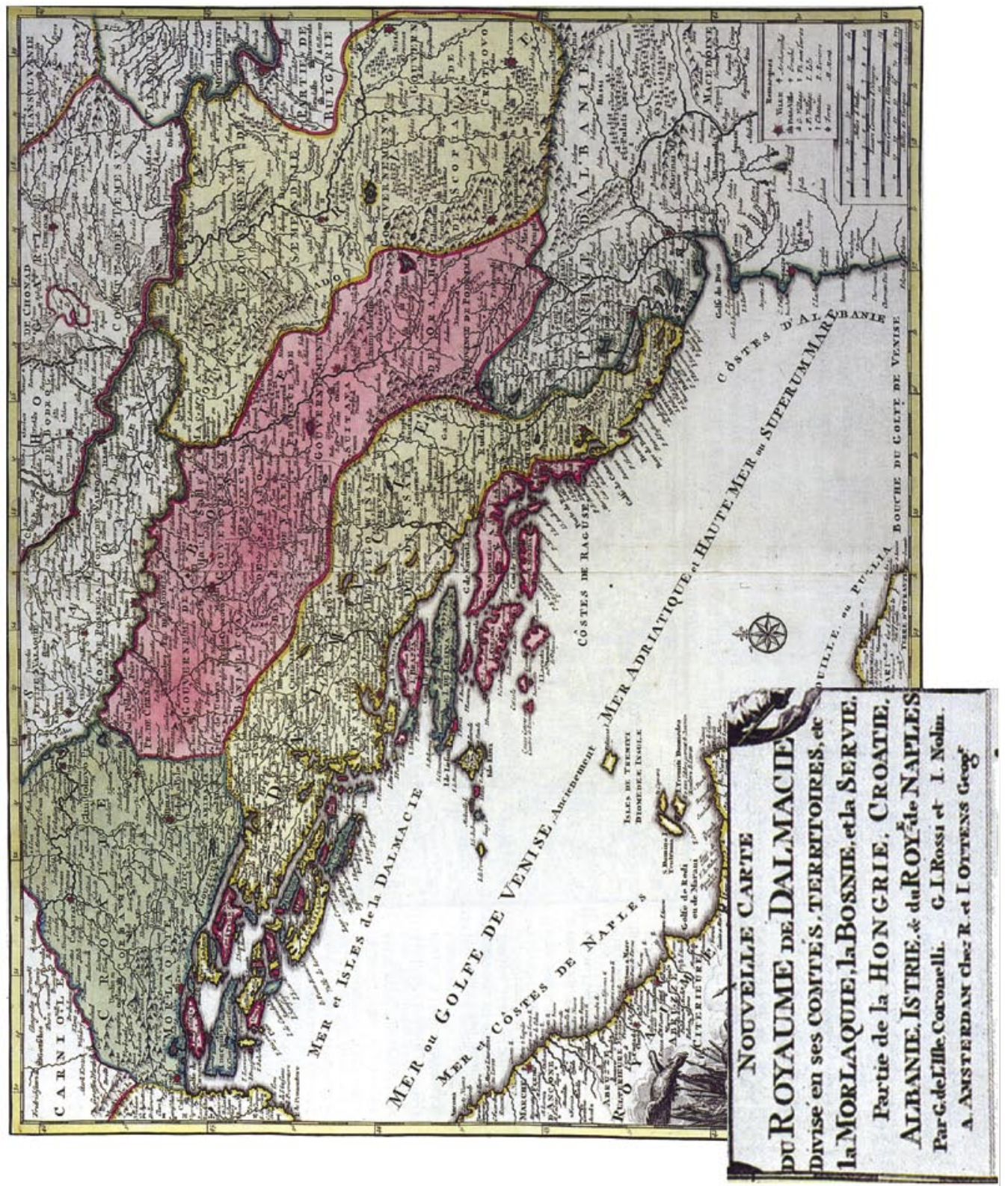

Fig.1. Coronelli's Map of the Kingdom of Dalmatia, La Morlaquie, Bosnia and Serbia..., 1700. (Facsimile from Marković 1993). Title emphasized by the authors.

Sl. 1. Coronellijeva Karta kraljevine Dalmacije, Morlakije, Bosne i Srbije..., 1700. (Faksimil iz Marković 1993.). Naslov karte istaknuli autori. 
the $18^{\text {th }}$ century was a time of relatively numerous changes of the border in Dalmatia ${ }^{3}$ and a time of intensive cartographic work. Demarcation maps from that time present the very first topographic presentation of the Dalmatian hinterland. Alberghetti's supplemented map of Dalmatia from 1732 presents three borderlines; the old one from 1671 (Linea Nani), the one from 1700 (Linea Grimani) and the newest one from 1720 and 1721 (Linea Mocenigo). The map contains the administrative division of the territory that most Venetian maps have. The topography is very detailed except orography and communication. Beyond the border, there is no presentation whatsoever, except for some very general textual notions of what may be found: "Parte della Lica", "Parte della Bossina", "Ercegouina". Thus, the central element of the map is the development of the Venetian - Ottoman border, in terms of territorial extension of Venetian republic, disseminating the message of the Republic's power and control over the territory. An obvious ignorance of Ottoman presence is shown through the omission of recording their territory across the border, except parts of the regions of Lika, Bosna and Herzegovina. The omissions are as important as emphasizing in disseminating the political messages of the maps.

In spite of the significant differences in a technical sense, i.e. descriptive and "scientific" cartography, there are some unifying and constant elements that characterize the Venetian cartography of their borderlands. That is the emphasizing and over-enlarging its possessions and importance. The maps have fulfilled their function in exercising power and control, in promotion and giving legitimacy to the territorial occupation.

Habsburg cartography was guided completely by military and strategic interests and needs. Highly aware of the extreme importance of knowing the border area in the strategy of warfare, the Habsburg cartographers already surveyed and mapped the territory long before the $18^{\text {th }}$ century. The occasion of the peace treaty of 1699 and the need to fix the new border between the Habsburg Monarchy and the Ottoman Empire was the direct cause of the first topographical survey and the appearance of the first genuine topographical maps of the territory along the border.

The central interest in the new border is shown on Christoph Weigl's map of the Imperial - Turkish Border after the peace treaty, made presumably around 1702 (Pandžić 1988, 99). The only theme of the map is the border, which is the only colored element on the map. On the maps, understood as images, the color has always been a very strong tool. Different colors send different messages to the audience. Strong, cardinal colors, as the red color for instance, were always the imperial colors etc. There is not much content outside the borderline except a rich inventory of military fortification on the margins of the map, talking about the undisputable power, security and the organization of the Monarchy.

On the third count, one can notice one more specific approach to the territory and borders of Croatia. Dissatisfied with the newly established borders accorded by the peace treaty of Srijemski Karlovci, the Croatian representative and cartographer P. Ritter Vitezović tried to present to the Austrian court his view of the "real historical" borders and territory of Croatia (Marković 1987). Apart from a number of topographical maps and sketches of the newly established border area made during his work in the demarcation commission, he made a map of the whole kingdom of Croatia (Fig. 2). The map was made in 1699, representing the entire kingdom of Croatia in its ancient, historical limits as confirmed 


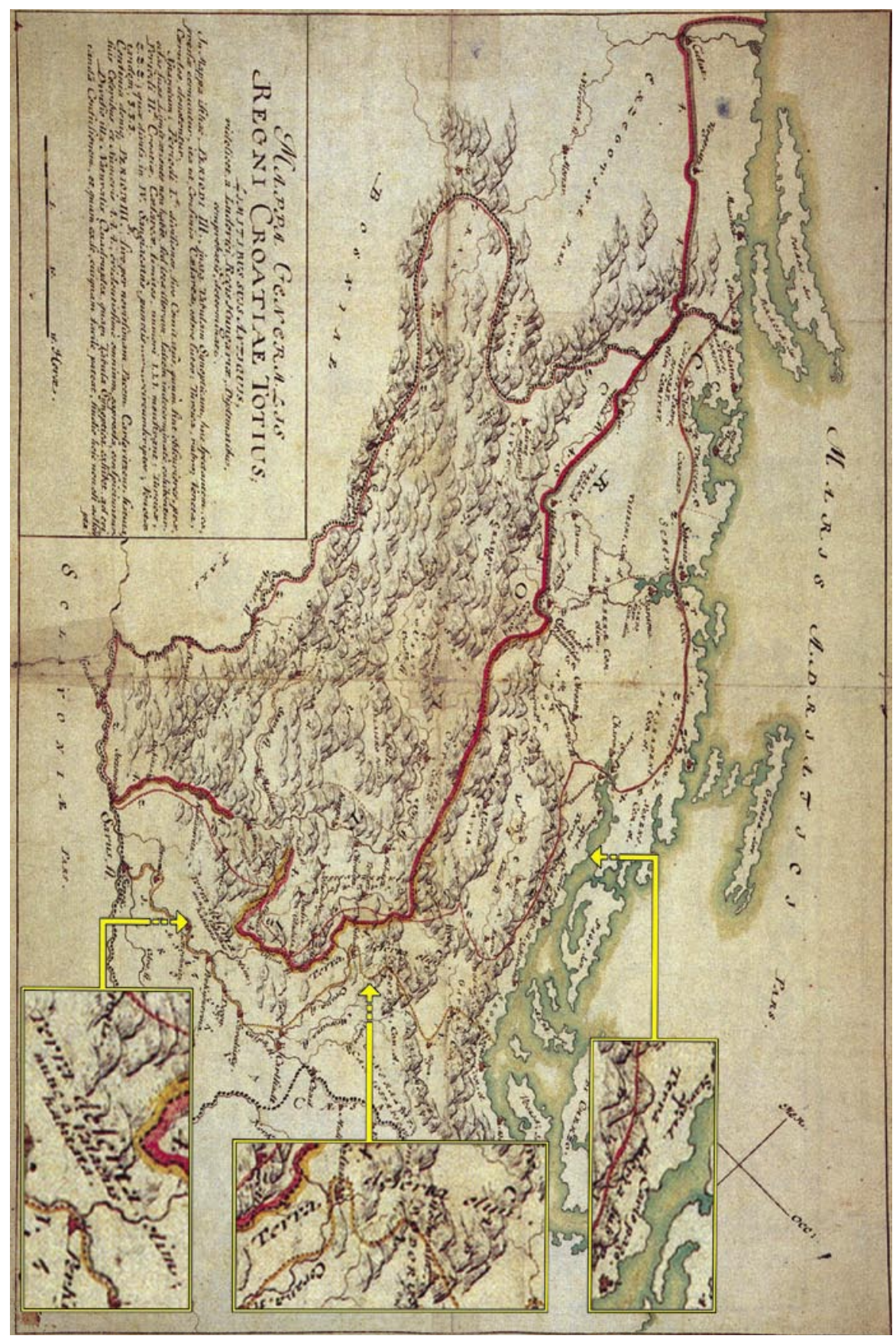

Fig. 2. Vitezović's Map of the whole Kingdom of Croatia, 1699. (Facsimile from Marković 1993). "Terrae desertae" emphasized by the authors.

Sl. 2. Vitezovićeva Karta cijelog hrvatskog kraljevstva, 1699. (Faksimil iz Marković 1993.). "Terrae desertae" istaknuli autori. 
by the Hungarian king Ludovic in the $16^{\text {th }}$ century. Along with the 1699 demarcation, he drew in the former borders. The eastern border follows the line of the Vrbas river in contrast to the actual one on the river Una lying more westerly and thus, compressing the Croatian territory, while the Cetina river marks its southern border. The map is followed by the document named "Croatia Rediviva" and dated 1700. It represents an attempt by the author to establish the fact that the historical borders of Croatia were considerably larger than those established in his own time. Beside the far-reaching consequences of the future annexation of Dalmatia to Croatia, Vitezovic in fact formulated with his work a political programme that would have an important influence on the members of Illyrian Movement (Perković 1995).

\section{SOCIO-CULTURAL IMAGES OF THE BORDERLAND: MORLACCHIA, TERRAE DESERTAE, AND TURKISH CROATIA}

At the second level of the meaning, maps reveal the most common socio-cultural images of the borderlands. They reveal the characterization and differentiation of social groups, related system of beliefs, as well as environmental perceptions of the borderlands and the prevailing understanding of the "real" Croatian territory as opposed to the new (and actual) delimitation. Unlike cartographic expressions of different state power interests, those, may we say, spontaneous images are found to be common to all imperial, as well as cartographic traditions.

There are three expressive images of the Croatian borderlands, mainly imprinted through toponyms and some specific descriptions. The first one presents the area as a land of Morlacchi population, pointing to the differentiation of a distinct social group, while the second one is related to the environmental perceptions of the borderlands as depopulated and devastated area. It is, furthermore possible to establish a specific relation between the two. The third one refers to the border territory between two borderlines, the old one prior the Ottoman conquest and the new one of 1699, still considered (Turkish) Croatia.

The toponyms Morlacha or Morlacchia with a number of some other corresponding forms such as Morlacca, Murlacha, Morlakia, appear on the maps as oronymes, denoting the mountain Velebit, as well as toponyms, denoting the borderlands region. Toponymy and perception of space are very closely related. Those toponyms come from the term Morlacchi, the Venetian name for a distinct social group, also known as Vlach population. They can be found on such maps as early as the $16^{\text {th }}$ century. Analysis showed that this term, although originating in the Venetian tradition, spread and became a common name not just for the social group, but also for the area along and across the border. Thus, the term has got a spatial notion and corresponding form.

The expression "Morlacca detta Podgorie" is found on Alberghetti's map of Dalmatia (1732) for the area of the southern Velebit. Coronelli (1700) is using the form "La Morlaquie" to denote the distinct region. As there is not any presentation of relief on that particular map, the toponym certainly does not correspond to the mountain. On some of his other maps $(1688)^{4}$ he distinguishes the Velebit mountain as "Monti di Alben ol. Albius Mons". At the same time, he named the sea channel beneath the Velebit mountain" as "Canal de 


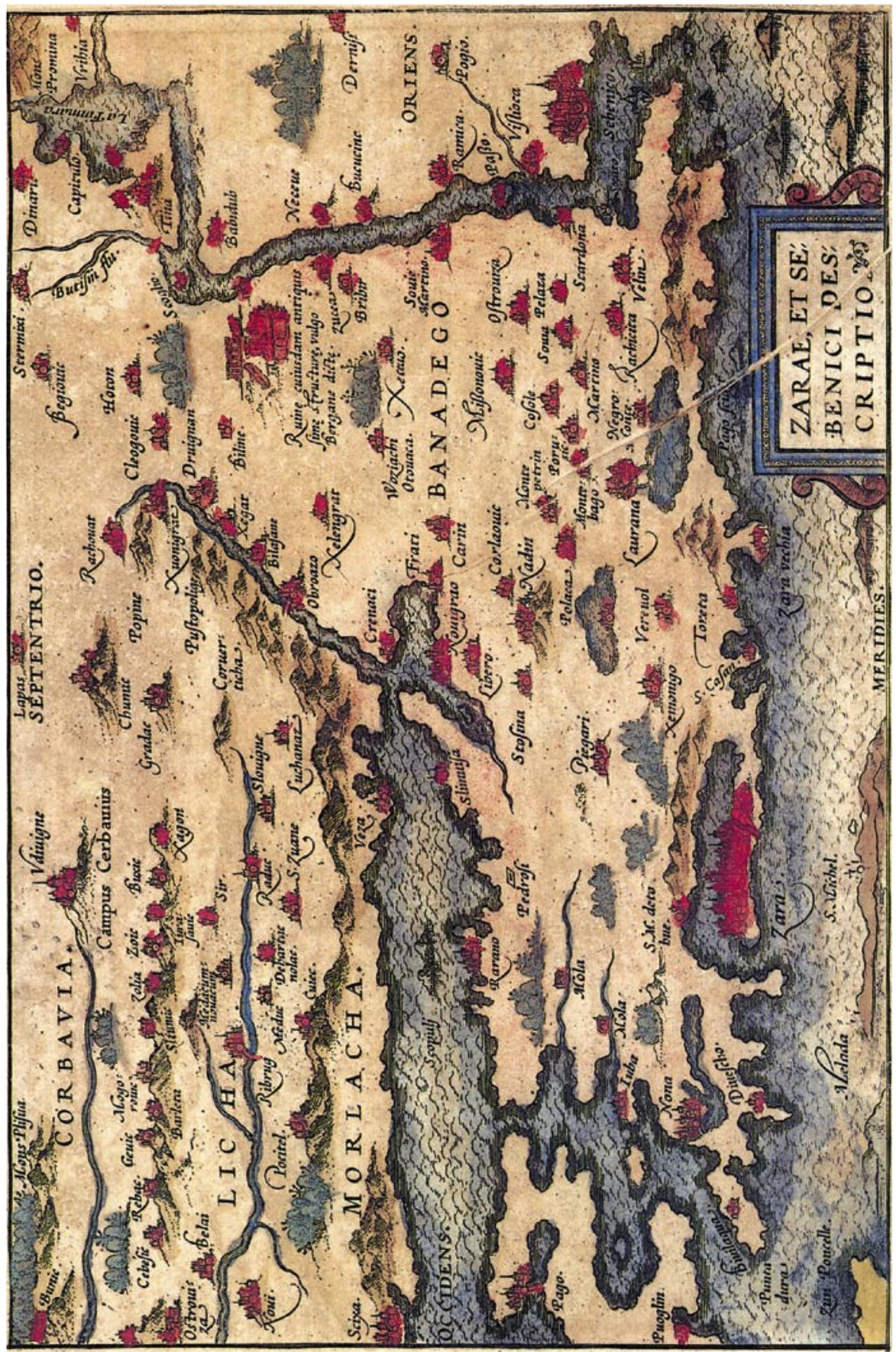

Fig. 3. Bonifačić's Map of the surroundings of Zadar and Šibenik with the region of Morlacha, 1573. (Facsimile from Marković 1993).

Sl. 3. Bonifačićeva Karta okolice Zadra i Šibenika s morlačkom regijom, 1573. (Faksimil iz Marković 1993.). 
Morlaquie". One more reason for the presumption that La Morlaquie is used as a toponym denoting the region is the title of the map ${ }^{6}$ from 1700. According to the title, the map is presenting the Kingdom of Dalmatia, Morlaquie, Bosnia and Serbia (emphasis B.F.B. and I.Z.), regions of equal and high range. There are also a number of similar examples of using the toponym Morlacchia for the Venetian border region of various cartographic origins (for instance: Pagano, Camocio, Bonifačić, Mercator, Stier, Cantelli da Vignola, Santini, Lučić, Sanson, Seutter, von Reilly...; Fürst-Bjeliš 1999-2000) (Fig. 3).

Vitezović, for instance, in the same period and on the same maps named the Velebit mountain range as "Velebich mons", and the sea channel as "Morlakischen Canal" (1699) or "Canale Morlaci" (1702). He had obviously distinguished the mountain as a relief form and its name from the different concept of the Morlacchian region, marked by the presence of the distinct social group. His maps reveal the relation between Morlacchia and Vlachs as well ${ }^{7}$. On his map of the whole Kingdom of Croatia (1699) he stated, by the map inscription "Terra deserta olim nunc a Valachis habitata" (emphasis B.F.B. and I.Z.) that there was a Vlach population inhabiting the deserted border area along the river Kupa. He obviously made a difference between the general name of the social group (Vlachs) and the spatial concept of the Venetian part of the border (Morlaci, Morlakischen). Additionally, the statement that the "depopulated land" was yet inhabited by Vlachs, expresses a very common image of Vlachs as a different and distinct social group (Fig. 2).

Originating from the Venetian term, the derived toponymic forms became the common name for the border region for more than three hundred years in circumstances where three imperial forces met. It has been clearly proved (Fuerst-Bjeliš 1999-2000) that all relevant European cartographic traditions that normally do not use the term Morlacchi but Vlach as a base used the term equally. This toponym and its several distinct forms have got a spatial sense and became a precise spatial concept. At the end of its development, it acquired a prevailing sense of a border region. With the disappearance of the specific border circumstances in the $18^{\text {th }}$ century, the spatial concept disappeared from the maps as well.

Coming back to the aforesaid statement "Terra deserta olim nunc a Valachis habitata" by Vitezović we are about to open a new question of environmental perceptions of the borderlands. Now, the other part of the statement shall be emphasized: "Terra deserta". The same map bears the inscription several times; in the border region along the river Kupa to the north, as well as in the area of Velebit littoral (Morlacchia or Podgorje) to the south. Vitezović saw, in fact, almost the whole area along the border as deserted and devastated (Fig. 2). Coronelli again is well recognized as the cartographer who likes to put on his map a lot of facts that he gathered. Apart from Vitezović's terrae desertae, one can find some other examples that witness about the devastated borderlands on Coronelli's maps (1688). He has recorded destroyed and abandoned cities and inhabited fortresses in the Venetian border region: "Starigrad Citta distructa", "Carlobago distructa", "Jablanac castello inhabit". Environmental perception of the borderlands as deserted, devastated, destroyed and inhabited area appears as common to all regardless their imperial or cartographic background.

Although Croatia regained a large part of its territories by the peace treaty of Srijemski Karlovci, it failed to get back some of its lands. That was, specifically, the area between the 


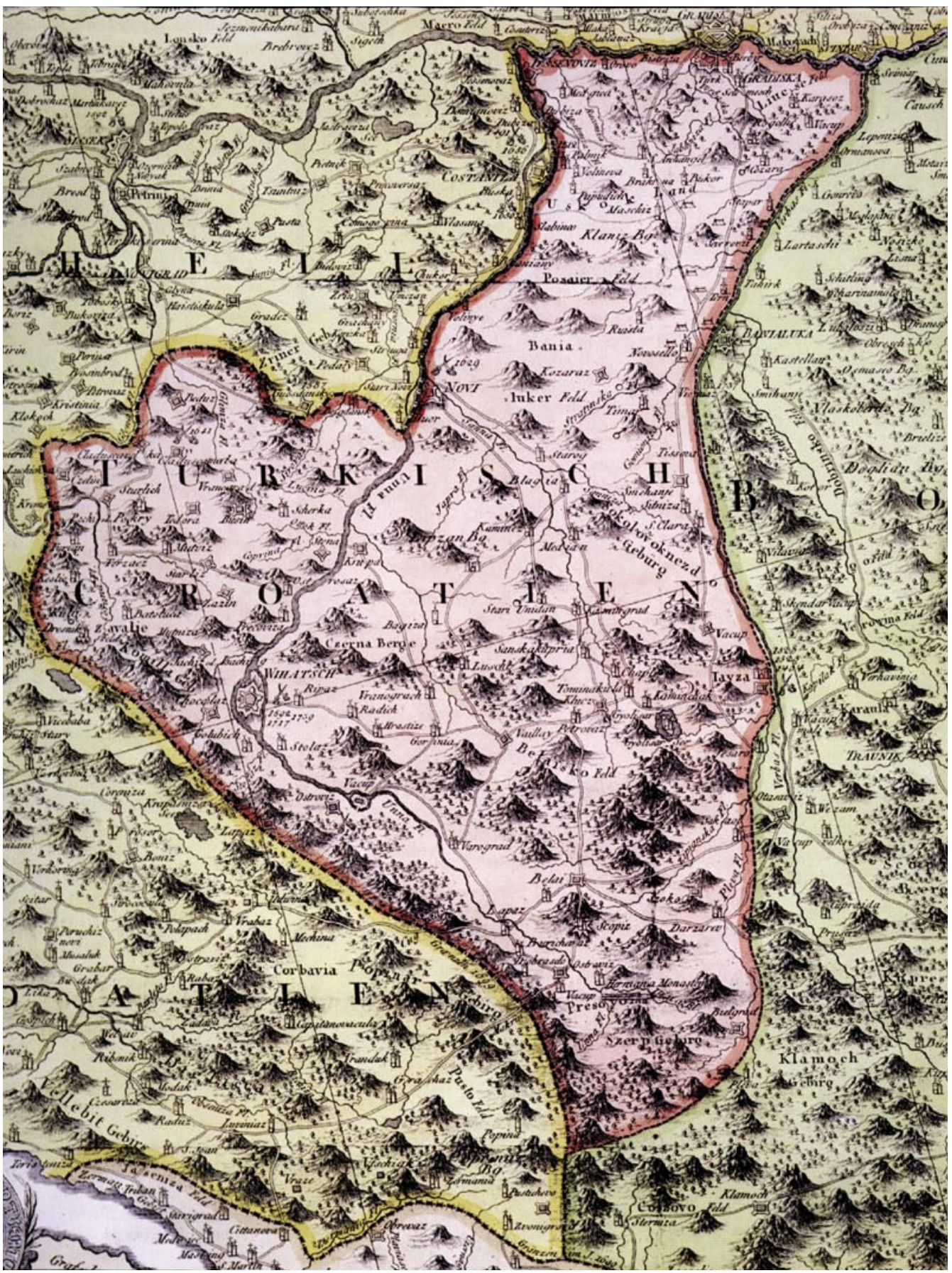

Fig. 4. Schimek's Map of the Turkish Croatia, 1788. (Facsimile from Marković 1998).

Sl. 4. Schimekova karta Turske Hrvatske, 1788. (Faksimil iz Marković 1998.). 
Una and Vrbas rivers - the area between the new and the old border, that the $18^{\text {th }}$ century cartographers usually denoted "Turkish Croatia". This fact reveals the image of the area as an integral part of Croatian territory in spite of the newly established borders. It also reveals the consciousness of its difference.

Some of the cartographers, along with the new border, drew in the old one as well. Some of the examples are Mueller's map of Hungary (1709) and Vitezović's map of the whole Kingdom of Croatia (1701). There are cases where this perception is expressed by an inscription, either a general one like "Croatia", or a more specific one like "Turkish Croatia", over the interfluves between the Vrbas and Una rivers. On Weigl's map of the Habsburg - Turkish border (1702), for instance, the inscription "Croatia", regardless of the actual borderline, is written across the river Una more easterly over the actual Ottoman territory, while Vitezović, on the same map, additionally distinguishes Turkish Croatia ("Croatia Turcica") as the interfluvial area between the Vrbas and Una rivers. Coronelli (1732), as a representative of the Venetian views, also marked a border territory of a certain width that differs in color from the rest of Bosnia, as well as from the rest of Croatia, lying under the inscription "Croacie". The example of Schimek's map ${ }^{8}$ of 1788 (Fig. 4), representing Viennese cartography, also shows the clear distinction in color of Turkish Croatia ("Turkisch Croatien"). This is an indication that, despite having recorded the new borderline, they perceived, or transmitted through the maps the actual perception of this condition as temporary.

There are several relationships that are expressed here; the old and the new border as the real, the historical border opposed to the new (temporary?) border; the difference in the system of beliefs - Christian Croatia opposed to Moslem Croatia. The image of the territory of Turkish Croatia, therefore, includes an awareness of religious identity and distinction as well. This image, as well as other examples of socio-cultural images of the Croatian borderlands, is common to all - Venetian, Habsburg and Croatian cartography, regardless their different political attitudes toward Croatian territory and borders.

\section{SOME CONCLUSIVE REMARKS}

Analyzing maps representing the Croatian borderlands in Harleyan postmodern terms they reveal two levels of meaning. The first one is related to the specific relation of the state authorities to the border region, their particular interests and understanding of its importance. The other one reveals common socio-cultural images of the borderlands.

At the first level one can put into relation three cartographies reflecting different attitudes regarding the borderlands: The Venetian, The Habsburg and Vitezović's cartographies are all disseminating the corresponding political message. Although opposed to each other, both Venetian and Habsburg maps are exercising the power and control of the imperial system, promotion and giving legitimacy to the territorial occupation. P. Ritter Vitezović expressed a more specific view of the Croatian territory and borderlands; he tried to present the "real historical" borders and territory of Croatia and in fact formulated a political programme that has influenced the Illyrian movement. 
At the second level of the meaning, maps reveal the most common socio-cultural images of the borderlands. They reveal the characterization and differentiation of social groups, related system of beliefs, as well as environmental perceptions of the borderlands as depopulated and devastated area and the prevailing understanding of the "real" Croatian territory as opposed to the new (and actual) delimitation. Unlike cartographic expressions of different state power interests, those images are found to be common to all imperial, as well as cartographic traditions regardless of their different political attitudes toward the Croatian territory and borders.

There are three expressive socio-cultural images of the Croatian borderlands and a number of relationships that are expressed here; the old and the new border as the real, the historical border opposed to the new (temporary?) border; the difference in the system of beliefs - Christian Croatia opposed to Moslem Croatia. The image of the territory of Turkish Croatia, therefore, includes an awareness of religious identity and distinction as well.

\section{NOTES}

1. On the Austrian side, the commission was led by Count Fernando Luigi Marsigli. His team consisted of a number of military engineers and cartographers. The great task of mapping the border was assigned to Johann Christoph Mueller. The demarcation of the new Ottoman - Venetian border after the peace treaties of 1699 and 1718 was carried out by Venetian representatives Francesco Grimani and Alviso Mocenigo. The borderlines which resulted from those peace treaties are called «Linea Grimani» $(1699,1700)$ and «Linea Mocenigo» $(1718,1720,1721)$. Mapping was assigned to a team of Venetian cartographers led by military engineer Giusto Emilio Alberghetti.

2. The Ottoman Turks used the term Rumelia for the Balkan. They took it from the Byzantine «Romei» (lands of the Eastern Roman Empire) (Orhonlu 1977, 281).

3. 1699 (1700) Peace Treaty of Srijemski Karlovci, 1718 (1720, 1721) (Peace Treaty of Požarevac), 1729 (corrections of the border at the mouth of the river Neretva).

4. V. M. Coronelli: Map of Istria and northern Dalmatia, 1688 (Kozličić 1995)

5. Its present name is Velebit Channel.

6. V. M. Coronelli: Map of the Kingdom of Dalmatia, Morlaquie, Bosnia and Serbia..., 1700, (Marković 1993).

7. In Croatian as well as in the German language there exists the term Vlach for this social group.

8. Maximilian Schimek, „The Kingdom of Bosnia and Herzegovina...“, Wien, 1788 (Marković 1998).

\section{REFERENCES}

Andrews J. H., 2001: Introduction: Meaning, Knowledge, and Power in the Map Philosophy, in Harley, J.B. The New Nature of Maps: Essays in the History of Cartography, The Johns Hopkins University Press, Baltimore, 1-32

Fürst-Bjeliš B., 1999-2000: Toponimija i percepcija u prostoru Triplex Confiniuma: Morlakija, Radovi 32/33, 349-354 
Borna Fürst - Bjeliš, Ivan Zupanc - Images of the Croatian Borderlands: Selected Examples of Early Modern Cartography

Fürst-Bjeliš B., 2000: Cartographic Perceptions of the Triplex Confinium and State Power Interests at the Beginning of the $18^{\text {th }}$ Century, in Roksandić D., Štefanec, N. (eds.) Constructing Border Societies on the Triplex Confinium, History Department Working Papers Series 4, CEU, Budapest, 205-220

Harley J. B., 1988: Maps, Knowledge, and Power, in Cosgrove D. and Daniels S. (eds.) The Iconography of the Landscape: Essays on the Symbolic Representation, Design and Use of Past Environments, Cambridge University Press, Cambridge, 277-312

Harley J. B., 1990: Introduction: Text and Contexts in the Interpretation of Early Maps, in Buisseret D. (ed.) From Sea Charts to Satellite Images: Interpreting North American History through Maps, University of Chicago Press, Chicago, 3-15

Harley J. B., 2001: The New Nature of Maps: Essays in the History of Cartography, The Johns Hopkins University Press, Baltimore

Kozličić M., 1995: Kartografski spomenici hrvatskoga Jadrana, AGM, Zagreb

Marković M., 1987: Prilog poznavanju djela objavljenih u zagrebačkoj tiskari Pavla Rittera Vitezovića, Starine $60,71-79$

Marković M., 1993: Descriptio Croatiae, Naprijed, Zagreb

Marković M., 1998: Descriptio Bosnae \& Hercegovinae, AGM, Zagreb

Orhonlu C., 1977: Geographical Knowledge Amongst the Ottomans and the Balkans in the Eighteen Century According to Bartinli Ibrahim Hamdi's Atlas, in Carter F. (ed.) An Historical Geography of the Balkans, Academic Press, London, 271-292

Pandžić A., 1988: Pet stoljeća zemljopisnih karata Hrvatske: izložba Povijesnog muzeja Hrvatske, Povijesni muzej Hrvatske, Zagreb

Perković Z., 1995: Croatia Rediviva Pavla Rittera Vitezovića, Senjski zbornik 22, 225-236

\section{SOURCES}

Anonim. Alberghetti's supplemented map of Dalmatia. Descrizione Topographica della Dalmazia. ca. 1:200 000. - 1700. HDA/KZ, E I 90.

Vincenzo Maria Coronelli, Jean Baptiste Nolin: Le ROYAUME DE/DALMACIE/ Divisé en ses COMTEZ, TERRITOIRES et c(etera) La MORLAQUIE, et la BOSNIE. 1:1 250 000. - 1700. PMH/KZ, 3802.

Pavao Ritter Vitezović: MAPPA GENERALIS/REGNI CROATIE TOTIUS;/LIMITIBUS SUIS ANTIQUIS,/ videlicet, a Ludovici, Regis Hungariae, Diplomatibus,/ comprobatis, determinati. 1:550 000. - 1699. HDA/KZ D I 60.

Johann Christoph Weigl: Mappa der zu Carlovitz geschlossenen und hernach durch zwei gevollmächtige/ Comissarios vollzogenen Kaiserlich - Türkischen Grantz - Scheidung, in dem früh jahr 1699. 1:11 300 000. - 1702. HDA/KZ, E I 90.

\footnotetext{
Abbreviations:

$\mathrm{PMH} / \mathrm{KZ}$ Museum of Croatian History/ Cartographic Collection

HDA/KZ Croatian State Archives/ Cartographic Collection
} 